In: Babich, ed., Reading David Hume's » Of the Standard of Taste «. (Berlin: Walter de Guyter, 2019).

Babette Babich

\title{
Signatures and Taste: Hume's Mortal Leavings and Lucian
}

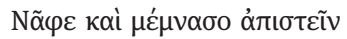 \\ [Stay sober and remember not to believe.] \\ - Epicharmus / David Hume ${ }^{1}$
}

\section{Of Books and Signatures}

In his introduction to his collection of David Hume's essays, Alasdair MacIntyre writes what surely wins the palm for an introductory first sentence to a book collection: "An introduction should introduce." 2 The point is elegant and MacIntyre is compelled to explain: "It should not be an attempt at a substitute for the book it is introducing."

In the essayistic case of David Hume's essays, and collections of the same, of which there are a number, Hume's essays speak for themselves, that is to say, apart from an 'advertisement,' without an editor's introduction. Additionally, there is a tradition of scholarly reflection on Hume's essays as such. The current collection adds to this and hopes to inspire reflection on what is arguably the most exceptional of Hume's essays.

"Of the Standard of Taste" was written to avoid damages threatened in response to the planned publication of Hume's Five Dissertations (a book including: "The Natural History of Religion," "Of the Passions," "Of Tragedy," "Of Suicide," and "Of the Immortality of the Soul”). The threats were promised by William Warburton (1698-1779), the influential theologian who subsequently

1 Written by David Hume on the back of his memoranda, and cited from Mossner, "Hume's Early Memoranda, 1729-40: The Complete Text," see here p. 503. Usually translated to the benefit of the tradition linking Hume and skepticism as "Keep sober and remember to be skeptical" but which translation sacrifices the injunction's negative force. Peter S. Fosl also features this epigraph in his “The Bibliographic Bases of Hume's Understanding of Sextus Empiricus and Pyrrhonism,” pp. 261-278. Fosl's essay begins by claiming that the use of the hermeneutic method in understanding modern philosophy ought to be traced to Richard Popkin. Fosl's claim is not accurate and although a student of Hans-Georg Gadamer's I might wish to favor Gadamer, Martin Heidegger or, given his priority, Heinrich Rickert or even just Leo Strauss, would seemingly be more likely candidates for the title of those "first to articulate a hermeneutical approach." To be sure, Fosl's focus is analytic history of philosophy which at times misses other approaches. 2 Alasdair MacIntyre, Hume's Ethical Writings: Selections from David Hume, p. 9. 
went on to become Bishop of Gloucester (and dedicated Shakespeare aficionado), who guaranteed a suit for excommunication of Hume and his cousin (the clergyman and playwright, John Home, author of Douglas;), ${ }^{3}$ as well as Hume's publisher Andrew Millar (1706-1768) were Hume's Five Dissertations to be published as originally designed. Millar duly urged Hume to revise the first essay and cut "Of Suicide" and "Of the Immortality of the Soul," literally slicing the final two sections from the already printed book. The three remaining essays were insufficient to make the book a book and Hume quickly composed "Of the Standard of Taste" to fill out the missing signatures, permitting the book to be published, with a new title, Four Dissertations.

The version of "Of the Standard of Taste" included here follows that same first publication, including punctuation, and spelling, if not to the letter $-\rho$ 's and all -indicating in brackets the pagination of the original printing. ${ }^{4}$ But if today's extant facsimile edition claims that it brings together, in the words of James Fieser: "the long-separated essays ... united as Hume intended," this would not be entirely precise. To such an end, one would need the original five essays, in accord with Hume's original design, less "Of the Standard of Taste" substituted in place of the elided essays. The socio-political and theological (and legal) reasons that compelled Hume to revise "The Natural History of Religion," i.e., the first offending essay, and to exclude his final two essays were thus quite different from his reasons for including "Of the Standard of Taste," although one might well read the essay itself as a commentary on the judgment, such as it was, that necessitated the exclusions.

To retrace this history, the first volume of the doubly initialed (T.H. Green and T.H. Grose) edition of Hume's Essays Moral, Political, and Literary, ${ }^{5}$ begins with Hume's autobiographical essay ${ }^{6}$ together with Adam Smith's letter to William Strahan, ${ }^{7}$ painting a detailed account of these same complexities, represent-

3 The essay by Jacob Sider Jost \& John Immerwahr, "Hume the Sociable Iconoclast: The Case of the Four Dissertations," is valuable on the topic of Douglas. See too for a more comprehensive, contextual background and for an understanding of Hume, of John Home, along with Henry Home or Lord Kames (1696-1762), Howard Caygill's comprehensive discussion in The Art of Judgment, a selection of which is included in his chapter below.

4 See David Hume, Four Dissertations and Essays on Suicide \& the Immortality of the Soul. Cf. Essays Literary, Moral, and Political by David Hume, Esq., The Historian, beginning with "Of the Delicacy of Taste and Passion". pp. 9-11 and "Of the Standard of Taste," pp. 134-149. 5 David Hume, Essays Moral, Political, and Literary.

6 Hume, “On My Own Life," in: Essays Moral, Political, and Literary, pp. 1-8.

7 Letter from Adam Smith, LL.D., to William Strahan, Esq., in Essays Moral, Political, and Literary, pp. 9-14. 
ed in the editors' preface, itself a piecing together of further letters, yielding "The History of the Editions." It is important to underscore that cutting the offending essays was simple. More delicate was the need to produce an exact range of additional pages - 40 pages having been cut with the loss of the two essays (38 pages) and the preface ( 2 pages) - such that "Of the Standard of Taste" 203240, in addition to its own title page (L1-2), kept the book at its necessary length of 240 pages.

Here, the signatures are key (the missing signature of the essays cut corresponding to the section letter $\mathrm{K}$, the replacement signature L, ending on 224, as one can still see this in the facsimile edition), ${ }^{8}$ and if the only thing that one needs to know is that "Of the Standard of Taste" was written to order and to printer's length - it is also essential to underline that only certain multiples of signatures make a book.

Why that should be so requires something of the contextual sensibility Hume tended to foreground in his own discussion of taste: a matter of delicacy, refined but not less scientific, ${ }^{9}$ and not less dependent on the culture of polite society but also technical precision and convention, as the "standards" for the same. "Of the Standard of Taste" would prove to be Hume's very last philosophical essay. ${ }^{10}$ And a relation to final things, including a philosopher's reflection on his philosophical legacy, including his contemporary reception, requires both convention and the optic of distance.

\section{Final Essays and Last Things, or Hume and Lucian}

A similarly relevant sensibility is needed for the question concerning which dialogue of Lucian's several "Dialogues of the Dead” Hume references in his final conversations with Adam Smith. The question is perhaps more esoteric than might have been necessary had one been able to assume a certain classically philological acquaintance than is in fact common among Hume scholars (or mainstream professional philosophers). But one cannot make such assumptions

\footnotetext{
8 Hume, Four Dissertations and Essays on Suicide \& the Immortality of the Soul, 201. The 'L' is centered in the bottom quarter of the page. The signature runs to p. 224, with the next signature 'M' beginning on p. 225.

9 See Hume, "Of the Delicacy of Taste and Passion." For a broad thematization beyond the framework of the current discussion, see Roger L. Emerson, Essays on David Hume, Medical Men and the Scottish Enlightenment: 'Industry, Knowledge and Humanity.' 10 See again, as cited above, Jost and Immerwahr, "Hume the Sociable Iconoclast."
} 
not only because of the state of professional philosophy (now nearly utterly 'analytic' which means more rather than less innocent of history) but also because Lucian, a $2^{\text {nd }}$ Century C.E. Syrian satirist who was once common coin among scholars when learning Greek was standard, has become less and less wellknown, an object illustration of changes in taste over time that Hume foregrounds. If taste and its deficits also correspond to "a lack of philology," as Nietzsche was fond of describing what Aristotle characterizes as "a want of learning," it is significant that the reference to Lucian was once so very standard it did not require disambiguation.

I corresponded about this with Annette Baier (1929-2012) before her own death - in the wake of her publications in both essay and book form on Hume on the question of 'last things,' including deathbed readings. ${ }^{11} \mathrm{I}$ also made acquaintance in the same way, via email, of the Milan Hume scholar Emilio Mazza whom Baier invokes in the same constellation. ${ }^{12}$

The mysteries of analytic and continental philosophy collide in this one strange node, on this one curious detail. Baier recounts her difficulties and not less her bafflement at even being asked the question, which dialogue? The easy solution, looking it up, sheds little light on the passage in question, as one then finds only those dialogues editors publish under the title: Dialogues of the Dead, such that Baier could only regard it as a puzzle that became more problematic the more she investigated it. ${ }^{13}$ In the end, Baier would resolve the question on the side of received convention, along the way carefully exploring the ambiguous reference to the dialogue. But, from a hermeneutic perspective, the puzzle evaporates if one has read Lucian and if one is not hoping, as Baier seemed to be hoping, to prefer one witness (Adam Smith's account) over another (one of Hume's attending doctors, William Cullen who names the dialogue). In addition, Baier adds a bit of biographical fancy - thus I understand some of the terms of her argument - by insisting that what is at issue must correspond to Hume's own life rather than to what is recounted in the dialogue itself, as Hume details this.

Baier doubts Hume's doctor, William Cullen's, direct account in a letter written at the time of Hume's death, identifying the dialogue by name, as Lucian's

11 Annette Baier, “Hume’s Deathbed Reading: A Tale of Three Letters,” pp. 347-356 and included, in revised form in: Baier, Death and Character: Further Reflections on Hume.

12 Baier, "Hume's Deathbed Reading," p. 349.

13 See, again, Baier (2006), "Hume's Deathbed Reading” and Death and Character, pp. 100 110. 
Kataplous, ${ }^{14}$ In the course of her hunt as instigated by Mazza's query, she tells us his name and later refers to Mazza again, namelessly, identifying his city of residence (Milan). A contribution by Mazza is included in this collection, albeit not directly on this theme, but which repays reading in this same connection. ${ }^{15}$ In order to preserve her interpretive scheme, and given her initial unfamiliarity with Lucian as she herself tells us, Baier makes the allusion more of a mystery than it is. On this point, we may recall Hume,

A thousand men may have a thousand different opinions about some one thing; but just exactly one of the opinions is true, and the only difficulty is to find out which one that is. ${ }^{16}$

Smith's account gives a generic title to Lucian's quintessentially sardonic Kató$\pi \lambda o u s$ ì Túpavvos, usually translated The Downward Journey or The Tyrant (in other translations the title is given as the Journey to Hell or Journey into Port), an all-purpose assault on religious persuasions, including the Greek, the Roman, the Jewish, the Christian and so on. ${ }^{17}$

As historian, Hume knew Lucian because of his aphoristic reflections on 'History.' In addition, Lucian is also the author of the tongue in cheek, 'A $\lambda \eta \theta \tilde{\omega} v$

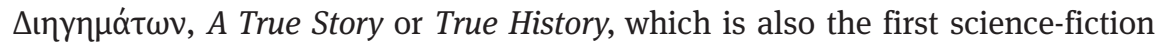
story and one of the first tall tales or lying tales, - one of Lucian's epithets is 'friend of lies' corresponding to his claim that where all other authors lie when they claim the truth, he, by contrast, quite by telling the reader in advance that he is lying, is the only author who tells the truth. Hume would likely also have read Lucian's dialogues for their elegant and amusing Greek in order to recoup, as he tells us he recoups ${ }^{18}$ his knowledge of Greek. Now the present editor knows Lucian's Kataplous not only for the same reasons - it is great fun to read in Greek - but not less, in the context of Nietzsche scholarship, because

14 William Cullen to John Hunter, 17 September 1776, in James Fieser, Early Responses to Hume, Life, and Reputations, p. 292 and cited in Baier, Death and Character, p. 103.

15 As Baier underscored again, in an email communication with the editor, she likewise acknowledges in a footnote: "This essay began as an e-conversation with Emilio Mazza, initiated by him" Death and Character, p. 110.

16 Hume, "Of the Standard of Taste," p. 208.

17 Lucian, Volumes 1-8. Cf. Lucian, Selected Satires of Lucian, and see too the contributions to Martin Ebner, Holger Gzella, Heinz-Günther Nesselrath, and Ernst Ribbat (Eds.), Philopseudeis è Apiston. Die Lügenfreunde oder: Der Ungläubige as well as for a discussion of Lucian although the topic of the essay is Menippus, Joel C. Relihan, "Menippus in Antiquity and the Renaissance" along with Christopher Robinson, Lucian and His Influence in Europe.

18 Hume, "On My Own Life," where, to be sure, he does not specifically refer to Lucian but just where the great ubiquity of Lucian had everything to do with both the purity of this Syrian's Greek and its pedagogic value. 
Nietzsche draws on this dialogue for his very complex conception of his Übermensch, echoing both Lucian's parodic sense of the term as it also recalls Goethe's ironic invocation at the start of Faust as expressed in the mouth of the Erdgeist. ${ }^{19}$ Nietzsche plays on this parodic sense fairly in the way Adam Smith celebrates David Hume's goodness as a human being by contrast with more churchly sensibilities. ${ }^{20}$

To consider this, an illustration can be helpful of another of Lucian's dialogues, Heracles. Dürer's allegory of eloquence features the central character, Hermes, dressed as Ogmios, the Celtic Hercules, ordinarily represented as an elderly figure.

Dürer opts for a less feeble and more youthful Hermes, representing the gobetween between the human and the divine, the world of the living and the realm of the dead, complete with thickly feathered winged boots, but outfitted with the rest of the attributes of Ogmios/Heracles, not only the dress of "lion's skin"21, following Lucian's description, but also dragging after him

a great crowd of men who are all tethered by the ears! His leashes are delicate chains fashioned of gold and amber, resembling the prettiest of necklaces. Yet though led by bonds so weak they do not pull back at all or brace their feet ... But let me tell you the strangest thing of all ... the ends of the chains ... [are pierced through] the tip of his tongue and [whereby the painter] represented him as drawing the men by that means. Moreover, he has his face turned towards his captives, and is smiling. ${ }^{22}$

Lucian continues, underscoring the source of his account as taken directly from the mouth of "a Celt at my elbow": for the Celts, we are told, the old Ogmios is a better candidate for eloquence than the youthful and fit Hermes, as eloquence is mightier than muscular force, moving its objects to comply willingly and represented by an old man, as age increases persuasive prowess where it withers other youthful capacities. ${ }^{23}$

19 Johann Wolfgang von Goethe, Faust, Volume 1 and 2, p. 19. See further, Babich, "Heidegger and Hölderlin on Aether and Life," p. 116.

20 Babich, "Nietzsche's Zarathustra and Parodic Style: On Lucian's Hyperanthropos and Nietzsche's Übermensch," pp. 58-74 and via Empedocles (and Hölderlin's recognition of political modernity and the still present dangers of tyranny), “Nietzsche's Zarathustra, Nietzsche's Empedocles: The Time of Kings" pp. 157-174.

21 Lucian, "Heracles," Volume 1, p. 63.

22 Lucian, "Heracles," Volume 1, p. 65.

23 Instructively this is a syncretistic - very fitting in the case of Lucian - representation of Hermes as Ogmios in Lucian's dialogue: Hercules. See for a summary of Lucian's description in addition to further references of which there are many, even beyond the listing provided here, and including patent connections with Hume, Jaś Elsner's chapter "Discourses of Style: 


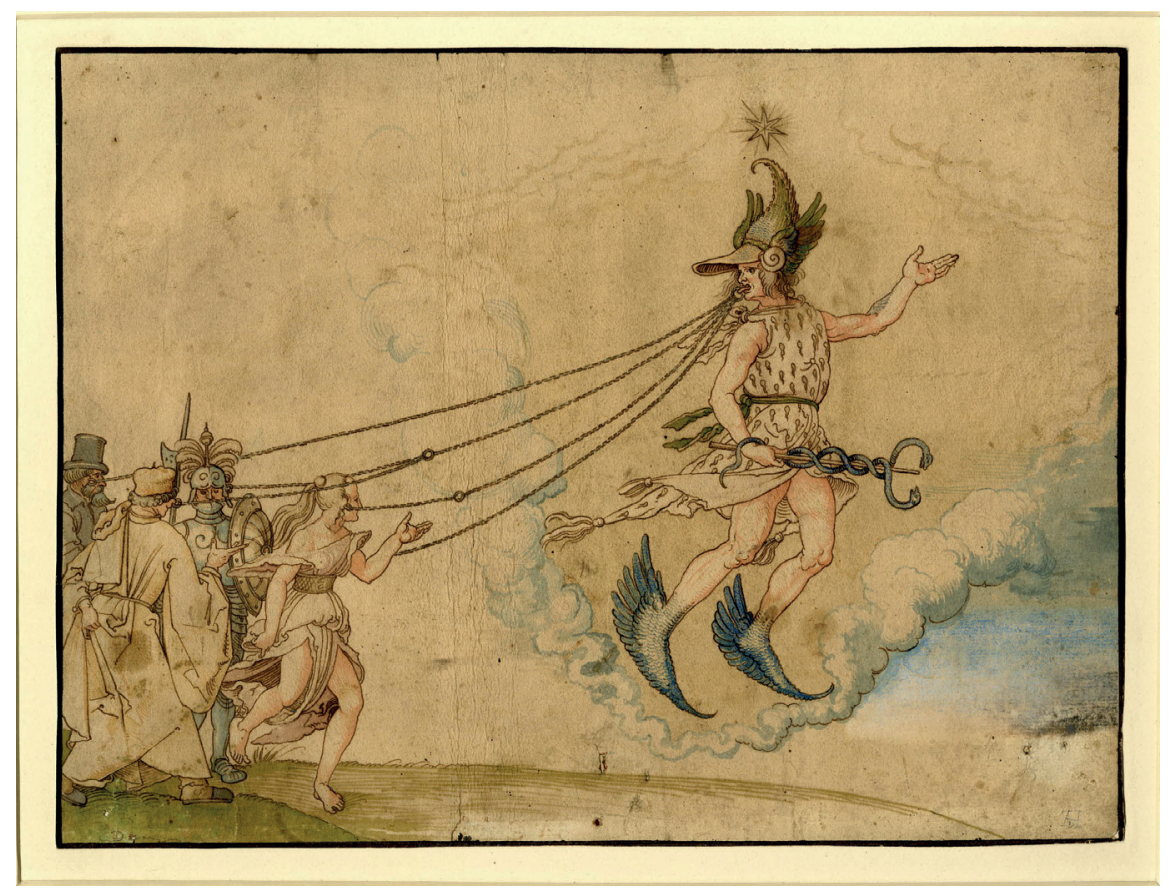

Figure 1: Albrecht Dürer, Allegorie auf die Beredsamkeit (Hermes mit vier irdischen Gestalten: Frau, Krieger, Gelehrter und Bürger) [Allegory of Eloquence (Hermes with four earthly figures: woman, knight, scholar, citizen)]. (1514) Wien Kunsthistorisches Museum. Color version courtesy of the British Museum. Public domain.

Dürer's allegory of rhetoric depicts Lucian's Hermes not only as leading his captives by the ear, chained with amber and gold chains piercing his own tongue, but as psychogogue: leading or guiding souls on their journey in this world and beyond it. ${ }^{24}$ It is as pychopompos, that Hermes appears in several of

\footnotetext{
Pausanias and Lucian," in his Roman Eyes: Visuality \& Subjectivity in Art \& Text, pp. 49-66. The tradition is a long standing one, see in French, F. Le Roux, "Les dieux celtiques aux liens: de l'Ogmios de Lucien à l'Ogmios de Dürer," pp. 209-234 as well as for discussion and further ref-


Bastin-Hammou, ed., Kaina pragmata: mélanges offerts à Jean-Claude Carrière, pp. 155-168. See too with respect to the artist's own image, Moritz Thausing, Dürer: Geschichte seines Lebens und seiner Kunst, mit Illustrationen und Titelkupfer, Vol. 1 on the cult of Mercury/Hermes, p. 297. 24 Additional studies connect Hume and Lucian with a death cult, not via the Kataplous and one analytically minded author strangely dismisses Annette Baier's argument but then proceeds to argue the same conclusion as she does (combining both Kataplous and the Dialogues of the Dead) albeit under a darker conventionality, see George Couvalis, "Hume's Lucianic Thanato-
} 
Lucian's dialogues, particularly the Kataplous, where we may recall a key vignette, recounting the supposed 'excuses' offered to avoid being carried off to judgment, excuses contradicted by the marks left on the soul by misdeeds in life, as Rhadamanthus explains, ${ }^{25}$ excuses given by the tyrant, the man of this-wordly power and wealth. Just these delimited protests correspond to Hume's words as Smith recounts them to us, offered to "Charon for not entering readily into his boat, [as for Hume it is not the case that] he could not find one that fitted him; he [Hume] had no house to finish, he had no daughter to provide for, he had no enemies upon whom he wished to revenge himself."26

Thus, the excuses instantiated are not generic: they are the excuses offered by the tyrant Megapenthes. Still what was key for Baier's puzzlement is the fact, as she observes, that the complaints are not indeed offered to Hermes [Mercury]. The point is duly repeated in the literature on the theme (including unattributed appropriations of Baier's argument ${ }^{27}$ but, hermeneutically speaking, as it were, any communication prior to entering the boat would perforce be via Hermes for whomsoever one might be meaning to address hoping for intercession, given

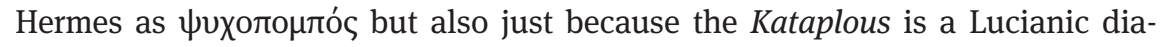
logue. Addresses to "lady Clotho," one of the three sisters of destiny, are in this sense and just in this particular context not less addressed to Hermes and Charon. Nor are these the only personages in the dialogue which is why Mycillus can chime in on just the same points as Hermes is the collector of souls, and it is this that Dürer's 1514 Allegory of Eloquence no less illustrates as his Hermes leads his band of souls, representing the Ogmios of Lucian's Heracles drawing an updated cast of personages, here depicted and as likewise variously detailed in the Kataplous.

The Kataplous is ultimately a dialogue of complaints, specifically being a litany of the laments accompanying the downward journey into that port that is the afterlife, the underworld. The tyrant, Megapenthes, has to address Hermes (even as his claim is addressed to Clotho to intercede on his behalf) as he hopes to avoid being taken on board, persuaded as he is of his importance (the shoemaker, Mycillus confirms that the tyrant had all the appearances in life of superiority,

therapy,” pp. 327-344 as well in connection with esoteric literature and economics and including Adam Smith in addition to Arthurian studies. See also Mazza's section "Lifelong Lucian and the Irish Skyths" in his "Hume's Life, Intellectual Context and Reception” in: Alan Bailey and Dan O'Brien (Eds.), The Continuum Companion to Hume, pp. 20-37, here pp. 28-30.

25 "For every wicked deed that each of you has done in his life, he bears an invisible mark on his soul." Lucian, The Downward Journey, 47.

26 Letter from Adam Smith, LL.D., to William Strahan, 11.

27 See Couvalis, "Hume’s Lucianic Thanatotherapy." 


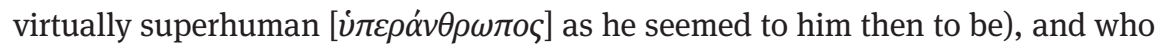
accordingly extensively protests being carried off, alternating bribes with threats, as he is not ready and hence ought not die. ${ }^{28}$

Hume's point, as Smith tells us, is that he himself could not be tempted to offer any of these excuses, as in his own case none apply. The one concern he mentions has to do with the fortunes of his writings, not less with his hopes to address important and ultimate things, specifically relevant to the fate of Five Dissertations (thence to the Four Dissertations as ultimately published), including what he might have in all probability intended among his last essays on the theme of last things: "Of the Immortality of the Soul." By contrast, the very last philosophical essay he would happen to write was less by design as the above essays would have been, than happenstance, an essay on taste, a cut that weighed on his mind, as an author concerned as he was throughout his life with his editions. In just this measure, Hume tells Smith that his only reserves are with ensuring that certain of his essays might finally see the light.

For Baier's part, just to go back to her hunt to identify the Lucianic dialogue of the dead in question, while assuming more precision than may have been justified by consulting the Loeb editions (eight volumes of them are at hand), Baier also elides a complex account of ancient Menippean satire, condensing it into Fielding and Swift, and so opting for overdetermination in order finally to settle the matter while insisting that the dialogues carrying the specific title of Dialogues of the Dead be exclusively identifiable as such. For Baier, the dialogical short arrays assembled under this title ${ }^{29}$ (many of Lucian's dialogues, as Baier duly notes, are generically dialogues between the dead) must be the referent (and contra Cullen's designation, merely present as he was at Hume's bedside, as the Kataplous), whereby Smith's unnamed and generic reference is accorded higher value. Baier summarizes that Hume "may have been reading more than one downward journey as spiritual preparation for his own," 30 a point which is perhaps true but not when it comes to the particular dialogue as she extends

28 Lucian, “The Downward Journey” in: Lucian, Vol. II, pp. 16-19.

29 Lucian's so-titled "Dialogues of the Dead" are short dialogues which Hume may well have been reading in addition to the above noted Kataplous, which are editorial compilations and arrangements bound together in the new Loeb edition, following Harmon's earlier version, with similar short forms under the titles "Dialogues of the Sea Gods," "Dialogues of the Gods," and, apparently, to round things out: "Dialogues of the Courtesans." Lucian Volume VII. See for a recent discussion attesting to the challenges of just these dialogues (formal and otherwise), Rafael Guimarães Tavares da Silva, “The Laughter Within the Dialogues of the Dead.”

30 Baier, Death and Character, p. 104. 
the claim. ${ }^{31}$ Nor indeed can the matter be settled as already detailed above simply by noting as Baier does "that the excuses are offered to Mercury rather than Charon" as, of course the excuses are offered in dialogue itself mediatedly, i.e., to "good lady Clotho." ${ }^{32}$ One of the advantages of classically hermeneutic philosophy informed no less by Gadamer than by Nietzsche ${ }^{33}$ is the recognition of the role played by Hermes/Mercury as go-between among gods and humans. At the end of the day, only Charon will matter when it comes to that journey.

Hence it is just as relevant, as this too informs Smith's reflection and not less Hume's own irony, that when it comes to religion Lucian's Kataplous is less a dialogue about the famous man Megapenthes than it is a dialogue about the 'good man,' good inasmuch as he is conscious of and at terms with his mortality. This is Mycillus, the shoemaker who, like Hume, having no attachments had no reasons for wishing to remain and no illusions about excuses that might spare him and thus comes running, literally so - no hesitation at all. At the outset of the dialogue we meet Mycillus identified not by name but as laughing and protesting to Clotho at having to be made to wait to board, by contrast with the others who seek any delay, however minor. When Charon chides this eager soul for his hurry, pointing out that the bark is full and that he can wait for the next ferry, Mycillus insists on coming aboard. This takes some persuasion and, when he is brought on board, as there is no space, he has to be told, on Hermes' orders and to Clotho's applause, to stand "on the tyrant's neck." ${ }^{34}$ The communal signifier and reference of laughter is one Bracht Branham rightly emphasizes, ${ }^{35}$ but here this shoemaker's laughter functions to singularize him. Thus, Hermes has to remonstrate "Nobody may cross without a tear": "Do cry, however, even if only a little, for custom's sake." ${ }^{36}$ Despite the parody of regret ('Alas my old shoes') duly uttered (more laughter), Mycillus' laughter is ongoing as the dialogue proceeds contra the Übermensch himself (the tyrant Megapenthes), ostensibly at the shoemaker's own expense as he laughs at himself for having been so taken in by the

31 Baier, Death and Character, p. 103-104.

32 Lucian, “The Downward Journey,” p. 16. Clotho is one of the fates who spins as we may recall Milton's words as the dialogue invokes the agency of Atropos, who cuts the thread of life. In the poem Milton writes on the drowning death of his friend, his Lycidas, "Comes the blind Fury with th' abhorred shears, / And slits the thin-spun life."

33 See for a discussion of hermeneutics in broader this context the contributions to Niall Keane (Ed.), Blackwell Companion to Hermeneutics, including, more specifically, Babich, "Friedrich Nietzsche,” pp. 366-377.

34 Lucian, "The Downward Journey,” p. 39.

35 R. Bracht Branham, Unruly Eloquence: Lucian and the Comedy of Traditions.

36 Lucian, “The Downward Journey,” p. 42. 
accoutrements, smells and tastes associated with the man who in life seemed a hyperanthropos, a higher human being:

I held him happy when I saw the splendour of his purple, the number of his attendants, his plate, his jewelled goblets, and his couches with legs of silver; besides the savour of the dishes prepared for his dinner drove me to distraction. Therefore he appeared to me a superman, thrice blessed, better looking and a full royal cubit taller than almost anyone else; for he was uplifted by his good fortune, walked with a majestic gait, carried his head high and dazzled all he met. ${ }^{37}$

Mycillus, the 'good man' does not merely come 'readily' - as Epictetus suggested that one always should be at the ready, ${ }^{38}$ - but gladly, laughing. Thus on an utterly different level, Hume showed himself, on Smith's parallel, to be good.

\section{De gustibus non disputandum est}

It is assumed that we know what classics are valued and that is why we call them 'classics.' We admire Milton and Shakespeare, Goethe and Schiller, Homer and Aristotle and Plato and so on. As a historian, David Hume raised another question, as historical sensibilities are liable to change such that some things that appear in their day to be sure classics, things that have until then withstood the test of time, can undergo a shift in value for another era. Hence the Lucian who was popular in Hume's own day and even through to the beginning of the $20^{\text {th }}$ century, has today so diminished in 'classical' value that he is sufficiently esoteric that Hume scholars like Baier have trouble tracking him down. The same is true for Homer and Archilochus, to cite the fathers of genres of epic and lyric poetry respectively, esteemed in equal measure by the Greeks, as Nietzsche will tell us, but which, just where Homer shines brilliantly as a classic to the current day (if John's Ogilby's translation as Hume mentions him has dimmed for us today and newer (re)translations of Homer's Odyssey excite attention instead), ${ }^{39}$ Archilochus remains sufficiently obscure that scholars insist that Nietzsche must be

37 Lucian, Downward Journey, 33.

38 Epictetus, Enchiridion, § 7. Cf. The Works of Epictetus A Translation from the Greek based on that of Elizabeth Carter, and Discourses of Epictetus.

39 See the literary scholar, Emily Wilson's new, “contemporary” translation of Homer's Odyssey now out with Norton a translation that has gotten significant attention less owing to its freedom than because she is the first woman to translate the Odyssey into English. By contrast, the Iliad exists already in a translation by Caroline Alexander. 
wrong in setting him equal to Homer. ${ }^{40}$ Scholarly claims that judgments made by other scholars are "wrong" (we see these in abundance in the essays below, notably in Shiner and Townsend among most of the others included here to a greater and lesser degree) may well be the only thing to endure (to use one of Nietzsche's phrases) "beyond the day after tomorrow."

The entire concern of this volume is all about the critical basis for such claims. How can we determine a standard for estimating tomorrow's likely classic, whether in the literary domain or other areas where taste plays a role? Hume's own example, ironically underlined as borrowed "not to draw our philosophy from too profound a source" (ST 216) from Cervantes' tale of Don Quixote's companion, cites Sancho Panza's account of a rustic sensibility, outing posh presumptions of supposed taste, underscoring the problematic tensions between social conventions - as nearly every chapter below discusses this example. Attesting to this ability is Hume's 'delicacy': judging, by subjective taste alone, the objective fact of the physical presence of an old leathern thong and a rusted iron key that had fallen into a cask of clichéd costly Malmsey wine. It is a yet further detail that this permitted Hume to cite a then wildly popular book, newly retranslated in English by Smollett and published by Hume's own printer, Andrew Millar (helpful pitches worked the same for books in Hume's day as they do on a television talk show or Twitter today). ${ }^{41}$ Hume's point in giving us such an example is that taste does not always follow expectations: more expensive wines are not necessarily better, and one generation's enthusiasm often fades with the shifts of fashion in the next generation - not to speak of the course of centuries. There are, as Roger Scruton emphasizes in his contribution below, cultural issues at work, questions of the contemporary or of the latest trends, as Giorgio Agamben, speaking of the couture culture of Milan reminds us, are often constant concomitants at all levels of supposed "delicacy." ${ }^{22}$ And there are gendered issues, as Hume suggests, he argues that the

40 I discuss this in Babich, "Nietzsches Lyrik. Archilochos, Musik, Metrik." See for an English version, Babich, "Nietzsche's Archilochus."

41 Miguel de Cervantes, The Adventures of Don Quixote de la Mancha. Cervantes, novel was originally published in 1605 and 1615, Smollet's was not the first translation, which was Thomas Shelton's version which appeared very quickly, the first volume in 1612, the second in 1620 . For some estimations, the most popular version of Cervantes was Charles Jarvas (or Jarvis) 1842 translation on which to be sure Smollett's translation was based. MacLachlan's chapter below makes reference to this translation.

42 Giorgio Agamben, "What is the Contemporary," pp. 40-41. 
"fairer sex" is often gifted with more refined discrimination, as Carolyn Korsmeyer's classic chapter below likewise argues. ${ }^{43}$

Thus, although as is routinely conceded: "there is no disputing concerning taste," Hume's point was that precisely such is - or better said, ought to be a matter of keen disputation. Indeed, nothing would be more valuable in matters of investment or speculation. Thus, as Hume pointed out, rather a great deal rides on this, especially in the business of wine where he first made his acquaintance with "taste" and "delicacy" (cf. ST 216) and, by extension, wine futures and, ceteris paribus, art futures.

In this sense, although the young David Hume wished to do nothing but pursue a life of letters, his lack of fortune compelled him to work for a living, which he pursued fortuitously as assistant to a Scots importer in France whose business included wine. This, among other reasons, including family connections and thrift (few decisions in life are settled upon for just one reason), was how Hume found himself in the company of the Jesuits of La Flèche. Working where needed, and conserving his resources by turn, Hume was able to write, which means that he also hoped for an alternative career, and thus published A Treatise of Human Nature. But the book was judged 'unintelligible' by its first critics - complicated works often demanding more of a readership than a readership is prepared to offer - such that Hume himself repudiated it as having fallen "dead-born from the press."

In hindsight, as we know (and it is precisely Hume's point that this knowledge comes too late), his critics were wrong. But what is at stake here with respect to Hume's "Of the Standard of Taste” is far more than a matter of judging what philosophic text is likely to have a future. There is also ironic counterpoise in offering an essay on just this topic in just this circumstance in order to fill out the missing signatures for a book.

More generally, just where, with relatively few exceptions, most writers on Hume flatten questions concerning irony, the more earnest question of determining a "standard" of taste would be invaluable for ${ }^{44}$ improving judgments concerning colleagues and friends on social occasions. What wine do they order?

43 For a discussion mixing additional cultural and gendered concerns see Monique Roelofs, The Cultural Promise of the Aesthetic, esp. pp. $57 \mathrm{ff}$.

44 See however Carolyn Korsmeyer's chapter here below, including a reference to John V. Price's 1965 usefully taxonomic, The Ironic Hume. See too and likewise, MachLachlan's chapter below in addition, though focusing more on play, Freydberg. I do not mean here to imply that Hume scholars fail to reference irony with respect to religion. See, including further references, Ton Vink, “David Hume: Sceptical Atheist or Religious Conservative?” For a historically contextualized discussion, see M.A. Box’s 1990 The Suasive Art of David Hume. 
What taste do they show themselves to have? And why, how justifiably, do we take ourselves to set the standard?

To keep to Hume's original examples in the business of literature, i.e., in publishing especially given the peer review that determines the future of a text in advance, the question looms today with different names: Tolstoy or Flaubert? Jane Austen or Ernest Hemingway - or why not J.K. Rowling? The question is by no means unrelated to the literary imagination itself, including the rise and fall of certain characters in the popular mind. Thus, if Sister Carrie is no longer much read unless assigned at university, Harry Potter and the Sorcerer's Stone would, by contrast, seem to be going great guns if Rowling's book is, one might argue, just as likely to be encountered in a literature as in a film or media studies course.

The point concerns what Kant named common sense, and it is the point Hume raised against nothing other the literary critic's judgment of literature as such, that is, for or against a work and whether a given text can be expected to be likely to become a classic or not, something Hume had already noted in the $18^{\text {th }}$ century. Literary fame is a matter of fashion and fad. Thus Hume's examples today will be less a matter of esteeming superior "elegance and genius" than a matter of names we recognize - the issue of recognition undergirding Theodor Adorno's point concerning contemporary musical tastes on the radio - and those we do not when it comes to distinguishing between "Ogilby and Milton or Bunyan and Addison.” (ST 210)

If fashions and fads fade, Hume's worry about literary "futures" induced him to use the parallel example of wine in order to reflect on the "standard of taste." 8 The alcohol allusion has an even broader history, as Simone de Beauvoir, who first tells us in her memoir La force de l'âge of the youthful rue Montparnasse evening together with comrades in philosophical arms at the time, recalling Jean-Paul Sartre, listening to Raymond Aron extol the benefits of phenomenology, using as illustration, the challenge of philosophizing about an apricot cocktail or - as Hume does, - a glass of wine. To this account can be added estimations of art more broadly: painting, architecture, sculpture, - and perhaps science and perhaps the market itself.

\section{The Volume}

The essays in the present volume accompanying "Of the Standard of Taste" offer a varying range of interpretations of this one text and reading between these different assessments can enhance an understanding of the breadth and complexity of Hume's essay. 
Regarded more comprehensively - and beyond the specific theme of "Of the Standard of Taste," - there has been sustained scholarly engagement with Hume's essays, complex as this history is, including a tumultuous focus, beginning in Hume's own lifetime of the falling out, on the one hand, between Hume and Rousseau..$^{45}$ Added to this is a complicated aesthetic "contest," at least as art historians assess these contests as "philosophical" disputes ${ }^{46}$ - this point being not rendered more perspicuous by considering the analytic-continental divide (and vigorous analytic denial of the very idea of any such distinction) that today haunts professional, disciplinary discussion ${ }^{47}$ apart from the historical complications added by the $18^{\text {th }}$ century articulation of what can seem to have been a parallel divide. To this must be added a more Brexit-minded focus on Hume and Smith (and the Scottish Enlightenment beginning by foregrounding the routinely not often-noted James Dunbar), ${ }^{48}$ but more recently still focussing on the same Adam Smith already discussed above with reference to Lucian (and Hume's deathbed reading). ${ }^{49}$

Where the lion's share of Hume scholarship continues to look to his political and moral theory, or to his work as a historian, or indeed and at the heart of philosophy proper, at his epistemology, specifically on the nature of causation (here represented in Shiner and, in connection with continental philosophy of science,

45 One might regard this is as the oldest instantiation of the Anglophone-Continental divide. See Robert Zaretsky and John T. Scott, The Philosophers' Quarrel: Rousseau, Hume, and the Limits of Human Understanding. An intriguing take on this is offered via the German language compilation, Sabine Schulz (Ed.), "Leben Sie wohl für immer": Die Affäre Hume-Rousseau in Briefen und Zeitdokumenten. And cf. Hume's own Exposé succinct de la contestation qui s'est élevée entre $M$. Hume et M. Rousseau avec les pieces justificatives.

46 I am grateful to Nigel Warburton for reminding me, on the most academically relevant social media platform (Twitter), of this debate. See further, David Fordham, “Allan Ramsay's Enlightenment: Or, Hume and the Patronizing Portrait,” pp. 508-524.

47 For a discussion indicating some of these complexities, see a dialogue series between the editor and the philosopher and gaming and AI theorist, Chris Bateman, beginning with "The Last Continental Philosopher."

48 Christopher J. Berry, Essays on Hume, Smith and the Scottish Enlightenment.

49 Dennis C. Rasmussen, The Infidel and the Professor: David Hume, Adam Smith, and the Friendship That Shaped Modern Thought, and see too his earlier (and more comprehensively articulated: The Pragmatic Enlightenment: Recovering the Liberalism of Hume, Smith, Montesquieu, and Voltaire. This is, to be sure, hardly limited to a recent concern, as some of the contributors to the current collection also make plain, see for example, W.L. Taylor, Francis Hutcheson and David Hume as Predecessors of Adam Smith. 
Babich), ${ }^{50}$ Hume's reflections on taste, are as central to aesthetics as to the philosophy of art and beauty (Scruton), including delicacy (Costelloe) - and not coincidentally juridical and critical reflection (Caygill), but also to art and as much to speculative or economic investment, as to 'standards,' (Kivy, MacLachlan, Costelloe, Townsend, Démuth/Démuthová), these including historical philosophical reflections (Caygill, Mazza), involving antiquity with Plato (Freydberg) as well as moving forward to Nietzsche (Babich), while also including questions of gender (Korsmeyer, but also referenced in Townsend, Démuth/Démuthová, and Mazza).

Significantly, as this is a volume dedicated to an essay written to take the place of excluded essays, this volume also and alas has its own excluded essays - chapters the editor had originally hoped to include but which could not be included owing to prohibitive publisher's fees. ${ }^{51}$ The one comfort to be taken here is that these particular texts are published, if not as easily accessible as one might wish for fruitful scholarship in the best sense of Nietzsche's "la gaya scienza” - Die fröhliche Wissenschaft.

By contrast, Hume's essays, at least initially, were suppressed: excluded from his Five Dissertations as already seen and quite for reasons of literary style or judgment (and parallels on such judgments of taste corresponding to Warburton on Shakespeare, versus Hume on John Home)..$^{52}$ To this extent, one might sidestep the kind of exaggerated claim sometimes made in writing about the virtues of a monograph or collective volume. It is not that Hume's essay "Of the Standard of Taste" has been neglected as it has been read in the extensive literature (see, for an overview, for a start, Costelloe's chapter

50 There are many discussions of causation and taste, including some of the contributions to the present volume. Noteworthy too is Mary Mothersill, "In Defence of Hume and the Causal Theory of Taste."

51 These missing contributions are available in print which is a comfort that did not apply, hence Hume's end of life regrets for his suppressed/excluded essays and to which I refer the reader to, here listed alphabetically Jonathan Friday, "Hume's Sceptical Standard of Taste"; Theodore Gracyk, "Delicacy in Hume’s Theory of Taste”; Jacob Sider Jost \& John Immerwahr, "Hume the Sociable Iconoclast: The Case of the Four Dissertations"; Jens Kulenkampff, "The Objectivity of Taste: Hume and Kant”; and Denise Gigante, "Purging Mist: On Hume, Humors, and Taste." An additional essay germane to the discussion of David Hume and taste (and wine) is featured in a collection I published in 2016, Steven Shapin, “The Sciences of Subjectivity.” See also, if more peripherally, Paul Guyer's discussion of Hume's influence on Kant in the last chapter of Guyer, Knowledge, Reason, and Taste: Kant's Response to Hume.

52 See again Jost and Immerwahr, "Hume the Sociable Iconoclast," and see too, for a sense of the original debate the letters on the topic in James Fieser, Early Responses to Hume's Life and Reputation: Volumes 9 and 10, pp. 75-76, in addition to Ernest Campbell Mossner, "Hume and the Scottish Shakespeare." 
below) with respect to classical and aesthetic judgment, as well as with respect to calculative evaluation or estimation. But Hume's essay on taste and the standard by which one might evaulate claims of the same all too often functions as a mere mention and there are no collective studies that have made this essay and its related concerns a central theme. The current collection offers a range of reflections for scholars of aesthetics, art and beauty, together with questions of disputations, addressed to students and to philosophers, both analytic and continental, not to mention the occasional oenophile, in addition to issues of diet, physiology, and anatomy, slightly contra Hume's own ambitions to establish a standard but for the sake of further thinking. Hume's essay is key to this undertaking and thus we begin with it below. ${ }^{53}$

\section{Bibliography}

Agamben, Giorgio (2009) "What is the Contemporary." In: Agamben, What is an Apparatus and Other Essays. David Kishik and Stefan Pedatella, trans. Stanford: University of Stanford Press. 39-54

Babich, Babette (2018) "Heidegger and Hölderlin on Aether and Life.” Études Phénoménologique, Phenomenological Studies. 2. 111-133.

Babich, Babette (2017) “Nietzsches Lyrik. Archilochos, Musik, Metrik.” In: Christian Benne and Claus Zittel (Eds.) Nietzsche und die Lyrik. Ein Kompendium. Frankfurt am Main: Springer/Metzler. 405-429.

Babich, Babette (2016) “Nietzsche's Archilochus." New Nietzsche Studies. Vol 10, Nos. 1/2 (2016): 133-170.

Babich, Babette (2015) “Friedrich Nietzsche.” In: Niall Keane, (Ed.) Blackwell Companion to Hermeneutics. Oxford: Wiley, 2015. 366-377.

Babich, Babette (2012) “Nietzsche's Zarathustra and Parodic Style: On Lucian's Hyperanthropos and Nietzsche's Übermensch.” Diogenes. 58(4): 58-74.

Babich, Babette (2013) "Nietzsche's Zarathustra, Nietzsche's Empedocles: The Time of Kings.” In: Horst Hutter and Eli Friedlander, (Eds.) Nietzsche's Therapeutic Teaching: For Individuals and Culture. London: Continuum. 157-174.

53 At the time of this printing, there is only an 'art' edition of Hume's essay as a stand-alone edition, an "indie" paperback, published by the online art journal, Post-Modern Times, David Hume, "Of the Standard of Taste: Post-Modern Times Aesthetic Classics." Previously, there had been an edition (now out of print) by John W. Lenz in the Library of Liberal Arts series, Of the Standard of Taste and Other Essays. To be sure, the essay is also available under the title of one of the other four dissertations (the four that were meant to have been originally published), On Suicide. In addition, it can be found among a wider selection of other essays in MacIntyre's collection, already cited above, Hume's Ethical Writings, as well as in Stephen Copley and Andrew Edgard (Eds.), Selected Essays. 
Baier, Annette C. (2008) Death and Character: Further Reflections on Hume. Cambridge: Harvard University Press.

Baier, Annette C. (2006) “Hume’s Deathbed Reading: A Tale of Three Letters." Hume Studies. Vol. 32, No. 2: 347-356.

Bailey, Alan and Dan O’Brien (Eds.), (2012) The Continuum Companion to Hume (London: Bloomsbury).

Bastin-Hammou, Malika (Ed.) (2009) Kaina pragmata: mélanges offerts à Jean-Claude Carrière (Toulouse: Presses Univ. du Mirail).

Bateman, Chris (with Babette Babich) (2016) “The Last Continental Philosopher.” http://onlya game.typepad.com/only_a_game/2016/11/babich-and-bateman-1.html. Last accessed 24 March 2018.

Berry, Christopher J. (2018) Essays on Hume, Smith and the Scottish Enlightenment. Edinborough: Edinborough University Press.

Box, M. A. (1990) The Suasive Art of David Hume. Princeton: Princeton University Press.

Branham, R. Bracht (1989) Unruly Eloquence: Lucian and the Comedy of Traditions. Cambridge: Cambridge University Press.

Caygill, Howard (1989) The Art of Judgment. Oxford: Blackwell.

Cervantes, Miguel de (1755) The Adventures of Don Quixote de la Mancha. Tobias Smollet, trans. London: Millar.

Copley, Stephen and Andrew Edgard (Eds.) (1993) Selected Essays. Oxford: Oxford University Press.

Couvalis, George (2013-2014) “Hume’s Lucianic Thanatotherapy.” Modern Greek Studies. Australia and New Zealand, 16-17, B: 327-344.

Cullen, William (1999) Letter to John Hunter, 17 September 1776. In: James Fieser (Ed.), Early Responses to Hume, Life, and Reputations. London: Thoemes. Vol. 1. 292.

da Silva, Rafael Guimarães Tavares (2015) "The Laughter Within the Dialogues of the Dead." Revele. Nr. 8, (May): 232-246.

Ebner, Martin, Holger Gzella, Heinz-Günther Nesselrath, and Ernst Ribbat (Eds.) (2011) Philopseudeis è Apiston. Die Lügenfreunde oder: Der Ungläubige. Darmstadt: Wissenschaftliche Buchgesellschaft.

Elsner, Jaś (2007) "Discourses of Style: Pausanias and Lucian.” In: Roman Eyes: Visuality \& Subjectivity in Art \& Text. Princeton: Princeton University Press. 49-66.

Epictetus (1758) Enchiridion, § 7. In: All the Works of Epictetus, Which are Now Extant. Elizabeth Carter, trans. London: Printed by S. Richardson

Epictetus (1865) The Works of Epictetus. Consisting of His Discourses, in Four Books, The Enchiridion, and Fragments. A Translation from the Greek based on that of Elizabeth Carter. Thomas Wentworth Higginson, trans. Boston: Little, Brown, and Co.

Epictetus (1904) Discourses of Epictetus. George Long, trans. New York: D. Appleton and Company.

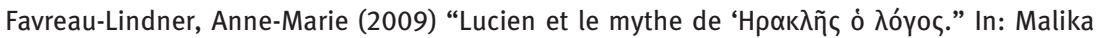
Bastin-Hammou (Ed.), Kaina pragmata: mélanges offerts à Jean-Claude Carrière. Toulouse: Presses Univ. du Mirail. 155-168.

Emerson, Roger L. (2016) Essays on David Hume, Medical Men and the Scottish Enlightenment: 'Industry, Knowledge and Humanity.' London: Routledge.

Fieser, James (2003) Early Responses to Hume's Life and Reputation: Volumes 9 and 10. London: Bloomsbury Publishing. 
Friday, Jonathan (1998) “Hume's Sceptical Standard of Taste." Journal of the History of Philosophy. 36: 545-566.

Fordham, David (2006) “Allan Ramsay's Enlightenment: Or, Hume and the Patronizing Portrait.” Art Bulletin. Volume 88, Issue 3: 508-524.

Fosl, Peter S. (1998) "The Bibliographic Bases of Hume's Understanding of Sextus Empiricus and Pyrrhonism." Journal of the History of Philosophy. 36:9 (April): 261-278.

Gigante, Denise (2008) “Purging Mist: On Hume, Humors, and Taste.” In: Taste: A Literary History. New Haven: Yale University Press. 54-66.

Goethe, Johann Wolfgang von (2012) Faust, Volume 1 and 2. Bayard Taylor, trans. New York: Modern Library.

Gracyk, Theodore (2011) “Delicacy in Hume's Theory of Taste." The Journal of Scottish Philosophy, 9/1: 1-16.

Guyer, Paul (2013) Knowledge, Reason, and Taste: Kant's Response to Hume. Princeton: Princeton University Press, 2013.

Hume, David (2013) Of the Standard of Taste: Post-Modern Times Aesthetic Classics. Birmingham: The Birmingham Free Press.

Hume, David (2005) On Suicide. London: Penguin.

Hume, David (2000) Four Dissertations and Essays on Suicide \& the Immortality of the Soul. South Bend Indiana: Saint Augustine.

Hume, David (1875) Essays Moral, Political, and Literary. London: Longmans, Green, and Company.

Hume, David (1870) "Of the Standard of Taste.” In: Essays Literary, Moral, and Political by David Hume, Esq., The Historian. London: Ward, Lock, and Tyler, Warwick House, Paternoster Row. 134-149.

Hume, David “On My Own Life.” In: Essays Moral, Political, and Literary. 1-8.

Hume, David (1757) Four Dissertations. London: Printed for A. MILLAR, in the Strand, MDCCLVII.

Keane, Niall (Ed.) (2015) Blackwell Companion to Hermeneutics. Oxford: Wiley.

Le Roux, Françoise (1960) "Les dieux celtiques aux liens: de l'Ogmios de Lucien à l'Ogmios de Dürer." Orgam 12: 209-234.

Lucian (1913-1967) Volumes 1-8. A. M. Harmon, trans. Cambridge, MA: Harvard University Press, Loeb Classical Library.

Lucian (1996) "Heracles." In: Volume 1. Harmon, trans. Cambridge: Harvard University Press, Loeb Classical Library 14. 1996 [1913]. 62-71.

Lucian (1968) Selected Satires of Lucian. Lionel Casson, trans. New York: Norton.

Lucian (1961) Lucian Volume VII, M.D. Macleod, trans. Cambridge: Harvard University Press, Loeb Library 431.

Lucian (1915) “The Downward Journey." In: Volume II, Harmon, trans. Cambridge: Harvard University Press, Loeb Classical Library 54, Vol. II. 16-19.

Jost, Jacob Sider and John Immerwahr (2013) "Hume the Sociable Iconoclast: The Case of the Four Dissertations." The European Legacy. Volume 18, Issue 5: 603-618.

Keane, Niall (Ed.) (2015), Blackwell Companion to Hermeneutics (Oxford: Wiley)

Kulenkampff, Jens (1990) "The Objectivity of Taste: Hume and Kant.” Noûs. Vol. 24, No. 1: On the Bicentenary of Immanuel Kant's Critique of Judgement. (Mar.): 93-110.

MacIntyre, Alasdair (1965) “Introduction.” In: MacIntyre, (Ed.) Hume’s Ethical Writings: Selections from David Hume. Notre Dame: University of Notre Dame Press. 9-17. 
Mazza, Emilio (2012) “Hume’s Life, Intellectual Context and Reception.” In: Alan Bailey and Dan O’Brien (Eds.), The Continuum Companion to Hume. London: Bloomsbury. 20-37.

Mossner, Ernest Campbell (1948) "Hume’s Early Memoranda, 1729-40: The Complete Text." Journal of the History of Ideas. 9/4 (October): 492-518.

Mossner, Ernest Campbell (Jul., 1940) "Hume and the Scottish Shakespeare." Huntington Library Quarterly. Vol. 3, No. 4: 419-441.

Mothersill, Mary (1997) "In Defence of Hume and the Causal Theory of Taste." The Journal of Aesthetics and Art Criticism. Vol. 55, No. 3: 312-317.

Price, John Valdimir (1965) The Ironic Hume. Austin: University of Texas Press.

Rasmussen, Dennis C. (2017) The Infidel and the Professor: David Hume, Adam Smith, and the Friendship That Shaped Modern Thought. Princeton: Princeton University Press.

Rasmussen, Dennis C. (2013) The Pragmatic Enlightenment: Recovering the Liberalism of Hume, Smith, Montesquieu, and Voltaire. Cambridge: Cambridge University Press.

Roelofs, Monique (2014) The Cultural Promise of the Aesthetic. London: Bloomsbury.

Schulz, Sabine (Ed.) (2012) "Leben Sie wohl für immer": Die Affäre Hume-Rousseau in Briefen und Zeitdokumenten. Zürich: Diaphanes Verlag.

Sider, Jacob \& John Immerwahr (2013), "Hume the Sociable Iconoclast: The Case of the Four Dissertations,” The European Legacy, Volume 18, Issue 5, pp. 603-618

Shapin, Steven (2017) “The Sciences of Subjectivity.” In: Babich (Ed.), Hermeneutic Philosophies of Social Science. Berlin: de Gruyter, 2017. 123-142.

Smith, Adam, LL.D. (1875) Letter to William Strahan, Esq. In: Hume, Essays Moral, Political, and Literary. 9-14.

Taylor, William Leslie (1965) Francis Hutcheson and David Hume as Predecessors of Adam Smith. North Carolina: Duke University Press.

Thausing, Moritz (1884) Dürer: Geschichte seines Lebens und seiner Kunst, mit Illustrationen und Titelkupfer. Vol. 1. Leipzig: E. A. Seemann.

Vink, Ton (2013) “David Hume: Sceptical Atheist or Religious Conservative?” In: Stanley Tweyman (Ed.) David Hume. A Tercentenary Tribute. Ann Arbor, Michigan: Caravan Books. $107-123$.

Zaretsky, Robert and John T. Scott (2009) The Philosophers' Quarrel: Rousseau, Hume, and the Limits of Human Understanding. New Haven: Yale University Press. 